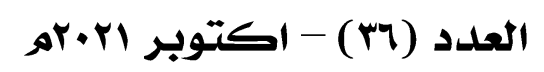$$
\text { مجلت كاليت التربيتّ - جامعت بورسعيل }
$$

\title{
Effect of a Proposed Unit on Color Idioms on Developing Cultural Awareness and Attitudes toward Translation among Non-specialist Students of English
}

\author{
Dr. Maged Mohammedain \\ EFL Instructor and the director of the \\ Languages \& Translation Unit of the Public \\ Service Centre at Faculty of Education, Port \\ Said University
}

DOI: JFTP-2108-1156

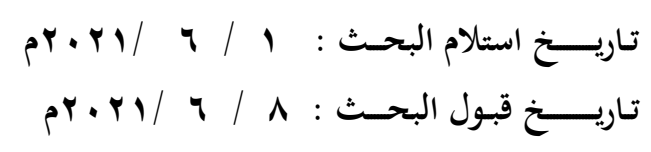

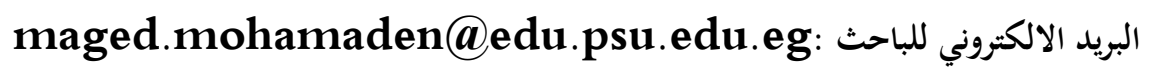

Faculty of Education Journal - Port Said University

Printed ISSN : 2090-5319

VOI. (36) - October 2021

On Line ISSN : 2682-3268

website : https://jftp.journals.ekb.eg/ 
Effect of a Proposed Unit on Color Idioms on Developing Cultural Awareness and Attitudes toward Translation among Non-specialist Students of English

Dr. Maged Mohammedain

\section{ABS'TRAC'}

Language is a tool of communication between cultures. Color idioms are language expressions that are used beyond their apparent meanings, using colors to express moods and feelings. They are culture bound and is only fully understood through understanding of their original culture. The aim of this study was to propose an instructional unit on color idioms, and investigate its effectiveness on the development of cultural awareness skills and attitudes toward translation among non-specialist students of English at Port Said Faculty of Education. It was an experimental study of onegroup design, conducted in the first semester of the academic year 2020/2021. Data were collected from (22) participants through two scales: a scale on participants' cultural awareness skills and another scale on their attitudes toward translation, both prepared by the researcher. Later, sets of data were statistically analyzed using different statistical techniques. The results of the analyses revealed that participants had developed their cultural awareness skills and maintain better attitudes toward translation. In the light of findings, necessary implications, suggestions for further research, and recommendations were provided for curricula and policy makers, researchers, teachers, and students regarding raising cultural awareness and developing positive attitudes towards translation.

\section{KEYWORIDS:}

Culture, cultural awareness, color idioms, attitudes towards translation

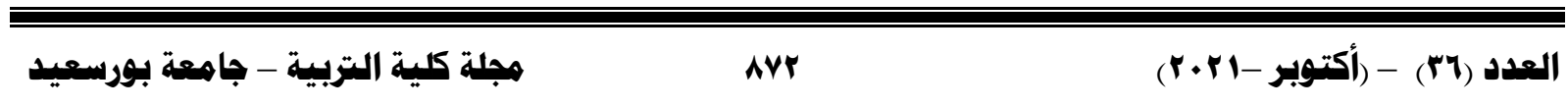


Effect of a Proposed Unit on Color Idioms on Developing Cultural Awareness and Attitudes toward Translation among Non-specialist Students of English

Dr. Maged Mohammedain

أثر وحدة مقترحة عن التعابير الإصطلاحية ذات الألوان في تنمية الوعي الثقافي والاتجاه نحو الترجمة لاي الطلاب غير المتخصصين في اللغة الإنجليزية

\section{vally}

اللغـة هـي وسـيلة التواصـل الأولـي بـين الثقافـات المختلفـة. والتعـابير الاصـطلاحية تمثل مكونــا

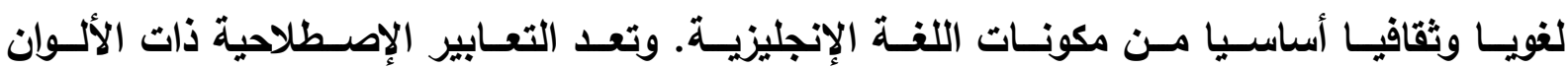

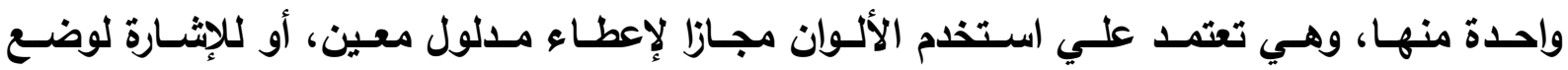

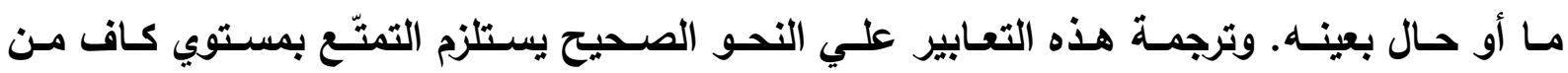

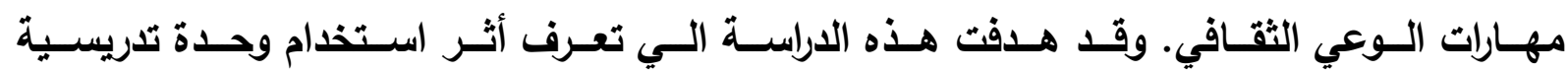

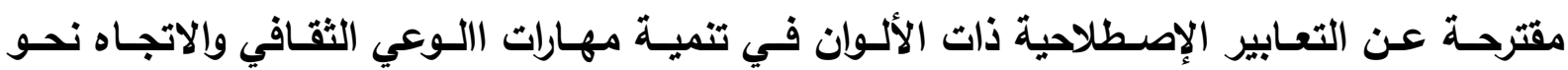

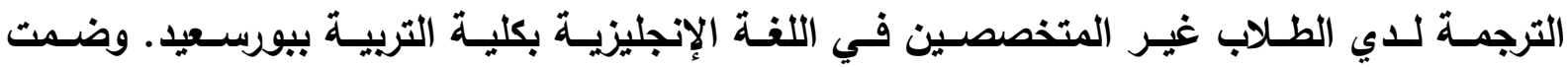

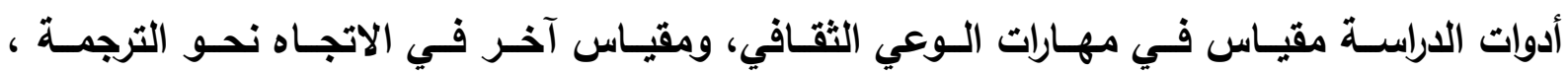

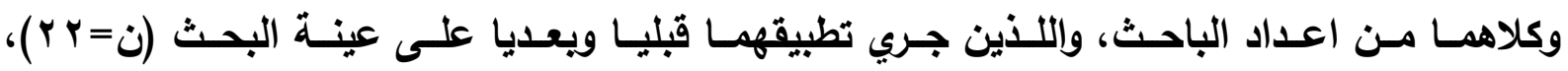

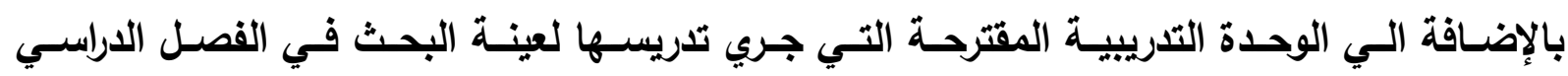

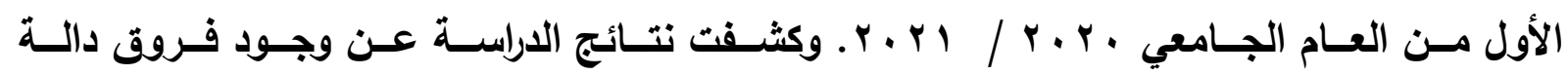

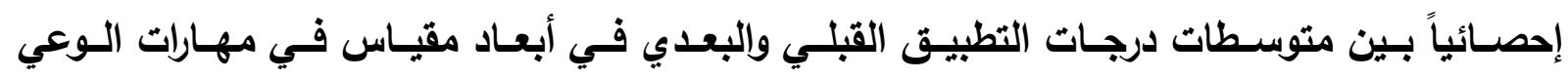

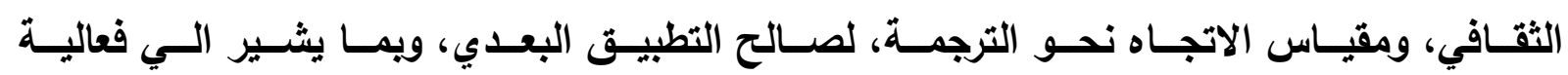

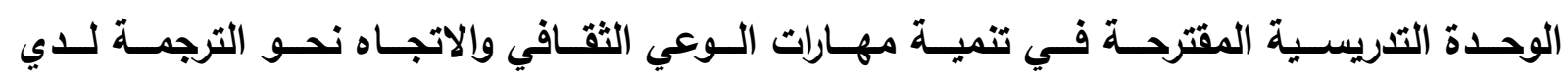

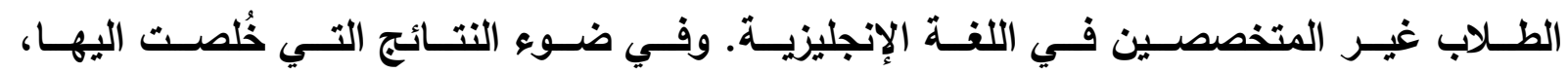

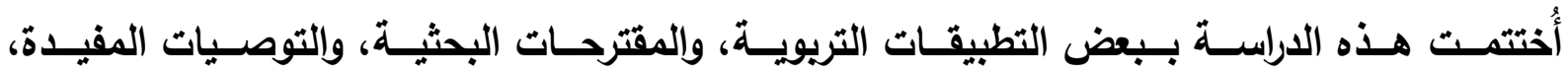
لمعلمي اللغة الإنجليزية ، وطلابها، وياحثيها ومطوري مناهجها.

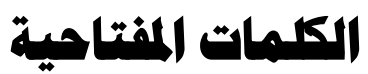
التعابير الإصطلاحية ذات الألوان، الوعي الثقافي، الاتجاه نحو الترجمة، الطلاب غير المتخصصين في اللغة الإنجليزية. 
Effect of a Proposed Unit on Color Idioms on Developing Cultural Awareness and Attitudes toward Translation among Non-specialist Students of English

Dr. Maged Mohammedain

\subsection{Introduction}

Learning a foreign language is thought to be a cultural experience. This idea is widely supported in research literature (e.g., Kahraman, 2016; Dweik \& Al-sayyed, 2015; Hesar \& Zarfsaz, 2012). Basically, the concept of "culture" refers to the social characteristics shared in common by a particular group of people living in a given community. Culture is made up of both non-material and material aspects related to people's way of life including language, religion, music, literature, values, beliefs, customs and social traditions which govern their society and affect the social environment they share, and the ethnics they have (Arabski \& Wojtaszek, 2011; Brown, 2007).

In this regard, culture and language are believed to be intimately connected (Aydemir \& Mede, 2014; Atay, et al., 2009). Language is the main tool that individuals use with one another for expression of their thoughts and feelings, for communication and sharing of knowledge, and for reflection of values, beliefs and perceptions of their surrounding world. Corbett (2003) states that, to learn a specific language means not only learning its alphabet, word order, and grammar, but also learning of a set of cultural traditions, norms, customs attitudes, beliefs, conventions, and values that are shared by the individuals speaking that language. Accordingly, learning a particular language, involving the English language, brings learners closer to how the people, who originally speak it, think, behave, communicate with others, and perceive their surroundings (Belli, 2018; Arabski \& Wojtaszek, 2011).

On this point, globalization of the English language, as being the dominant world language of science, business, and academia, increases EFL students' need for the development of their cultural awareness skills (Farooq, et al., 2018; Abdzadeh, 2017; Abushihab, 2016). There is no single accepted definition of cultural awareness in related literature. It is thought to be consciousness and aware of similarities and differences of cultural values, beliefs, and perceptions between two or more cultures (Kahraman, 2016:3). According to Tomalin \& Stempleski (2013), cultural awareness is an individuals' ability not only to see and comprehend the potential benefits of other people's values and beliefs; but also to accept their own personalities and beliefs. Moreover, Karabinar \& Guler, (2012) indicated cultural awareness refers to the qualities of openness and flexibility that one develops in relation to other people.

Relevant literature revealed that it is nearly impossible for language learners to understand the meanings and connotations of words and vocabulary without a satisfactory level of cultural awareness skills of the culture to which the target language belongs (Abdzadeh, 2017; Karabinar \& Guler, 2012; Mao, 2009). In the absence of cultural awareness skills, EFL 
Effect of a Proposed Unit on Color Idioms on Developing Cultural Awareness and Attitudes toward Translation among Non-specialist Students of English

Dr. Maged Mohammedain

learners tend to underestimate the importance of communication and collaboration with others. To begin with, Bada (2000:101) asserted the critical need for developing cultural awareness among language learners in order to avoid significant hardship in communicating meaning to native speakers, and assuming that the beliefs of other individuals are inaccurate, false and unacceptable. Besides, Belli (2018) believed that lack of cultural awareness hinders learners' ability to understand their own as well as the target culture, leading to inappropriate judgments about their cultural values.

Looking at idioms, they are originally language expressions which spontaneously convey the thoughts, emotions, traditions, customs and values exist in a specific culture (Yagiz \& Izadpanah, 2013; Kovecses, 2010). Primarily, idioms are multiword fixed expressions which represent a collection of prevailing phrases, sayings or groups of words used in a specific society to reflect a commonly cultural experience or shared social ideas and feelings. They are mainly composed of a number of words that are difficult to be fully comprehended separately, but helps language learners delve deeper into how feelings and thoughts are structured collectively in a specific culture (Galal, 2014). According to Baker (2011:67), idioms are frozen patterns of language often carrying meanings which cannot be deduced from their individual components as they are derived from the local culture.

There is an increased interest in researching idioms from a cultural perspective in related literature (e.g., Rezaeifard \& Chalak, 2017; Guineng, 2012; Al-Adaileh, 2012; Yang, 2010; Gvozdariov, 2009; Chielens, 2007; Grant \& Bauer, 2004). For instance, According to Grant \& Bauer (2004), idiom are a mirror of the culture they belong to and they generally have the following cultural traits: (a) their content may have been originated from historical incidents and contemporaneous conventions in society of the time, (b) they reflect social customs and habits affected by economy, politics and literary, (c) they reflect religious beliefs of people, (d) they reflect the geographical backgrounds of the place where people live such as water and temperature, (e) they reflect sports which occupies an important position in the lives of a particular group such as golf, soccer, rugby, hockey and boxing.

Traditionally, the English language is a one that is crowded with idioms. Color idioms are a part of idioms which have always been an issue for the discussion in related literature (e.g., Al-Adaileh, 2012; Turner, 2009; Chielens, 2007; King, 2005). Originally, color idioms are phrases or sayings used beyond their apparent meanings, using colors to express moods and feelings. Examples of color idioms in English may include "out of the blue", "green with envy", "gray area", and "black sheep". Color idioms are 
Effect of a Proposed Unit on Color Idioms on Developing Cultural Awareness and Attitudes toward Translation among Non-specialist Students of English

Dr. Maged Mohammedain

culture bound and is only fully understood through understanding of their original culture (Turner, 2009; Bortoli \& Maroto, 2008; Wright, 2004). Their meanings vary from one culture to another. For example, Bortoli \& Maroto (2008) stressed that green is the color of positive life concepts in most cultures such as inspiration, money, virtue, harmony, peace and hope. On the other hand, Wright (2004) indicated that it is the color of blindness, boredom and stagnation in other cultures. Turner (2009) linked blue to heaven, mercy, mystery and love; whereas Wright (2004) linked blue to unfriendliness, coldness and lack of emotions.

As idioms, including color idioms, are incorporated into a great deal of TEFL lessons and activities, they reflect the culture they belong to and be characterized as a culture specific element. EFL students always feel curious about translating idioms. However, there are many translation problems of idioms that are hard to overcome, including the uniqueness of the language and culture they originated in, and historical backgrounds (House, 2015; Salamah, 2015). Such problems may lower students' attitudes toward translation of color idioms, as EFL learner's main purpose has to provide precise and easily understood expressions (Ping, 2018; Shojaei, 2012).

Apart from the above-mentioned studies, there is little empirical research in Egypt and the Arab area, to the researcher's best knowledge, on the investigation of color idiomatic expressions in the development of cultural awareness skills. The majority of research on idiomatic translation has greatly concentrated on exploring commonly used or general translation skills, paying limited attention to cultural awareness skills (e.g., Al-Kadi, 2015; Manzoor \& Kiran, 2015). Added to this, little attention was paid to EFL students' attitudes toward translation, which is an important indicator of students' ability to translate color idioms accurately. Aiming to make a significant contribution, this study explored the effectiveness of using a proposed unit on color idioms in developing cultural awareness skills and attitudes toward translation among non-specialist students of English at Port Said Faculty of Education.

\subsection{The Problem Context}

Color Idioms are cultural and social in nature (Alotaibii, 2020). Related EFL studies agree upon a close link between translation of color idioms and the development of cultural awareness skills to comprehend and retain common idioms, and to avoid misinterpretation of the idiom meaning (e.g., Ping, 2018; Salamah, 2015; Shojaei, 2012; Allan, 2009).

However, this closed link is somewhat undervalued in Port Said Faculty of Education. This finding had been derived from the researcher's own observations and experience as a language instructor for non-specialist students of English who are provided with an English course aiming to 
Effect of a Proposed Unit on Color Idioms on Developing Cultural Awareness and Attitudes toward Translation among Non-specialist Students of English

Dr. Maged Mohammedain

create good opportunities for developing their abilities of communication based on their values, cultural norms, thoughts and needs; as well as develop their curiosity towards both the target and home culture. In such a course, they are exposed to authentic language materials, including a large group of reading, writing, speaking, translation and grammar tasks that seek to heighten their interest and increase their motivation for learning the English language.

However, the researcher observed that the cultural issues in the course are not addressed as well as possible by the assigned language teachers due to factors like shortage of time, lack of cultural knowledge, or lack of training as to which aspects of culture to teach, among other things. As a result, it was evident that non-specialist students of English lack openness and sensitivity to others' values and beliefs, and know little about the importance of understanding cultural differences. Some were unable to communicate and work effectively with other peers from diverse cultural and religious backgrounds. In this EFL context, language mistakes and misunderstandings were likely to occur, ones that can be avoided if they have a thorough understanding of the others' local culture. They were reluctant to participate when asked to provide translations of an idiom, especially color idioms. It was apparent that they did not comprehend color idioms in the right way. Gradually, most of them became too dependent on the lecturer, and developed negative attitudes toward translation of color idioms, causing them to lose interest in the course as well as increasing their feelings of tension and anxiety.

To survey this problem, the researcher conducted semi-structured interviews with a sample of (7) participants of non-specialist students of English enrolled in the second level at Port Said Faculty of Education. These interviews communicated to the researcher their frustration and worry about integrating idioms in particular, and cultural related aspects in their English course. Some confessed that they do not welcome engaging in language activities that include vastly different experiences because of their limited knowledge of the culturally appropriate behavior. Some expressed their unwillingness to seek more information and multiple perspectives of any language subject discussed. Some justified their inappropriate responses to their peers from diverse cultural and religious backgrounds to their limited knowledge of culturally appropriate ways to address, express gratitude, and agree or disagree with others.

Seemingly, the development of cultural awareness skills was a priority. Added to this, there was an apparent need among the non-specialist students of English at Port Said faculty of education to develop a coherent training course to help them learn color idioms, learn how to deal with other people and how to demonstrate empathy, effective engagement and 
Effect of a Proposed Unit on Color Idioms on Developing Cultural Awareness and Attitudes toward Translation among Non-specialist Students of English

Dr. Maged Mohammedain

tolerance, and establish the appreciation of similarities and differences among cultures. A well-constructed instructional unit was thought to be a good starting point for the non-specialist students of English to acquire the necessary cultural awareness skills.

With this in mind, a review of related literature was carried out to provide the researcher insight into the cultural competence and cultural awareness skills in language education classes. Cultural awareness skills were found a requisite to help language learners understand and accept cultural differences, get insight into the shared human needs, and be flexible and tolerant of others' ways of doing things (e.g., Kahraman, 2016; Dweik \& Al-sayyed, 2015; Lee, 2009; Wang, 2008; Corbett, 2003). What is more, the findings of related literature confirmed that color idioms mirror the cultural values of the society in which the language is spoken. They have unique cultural connections which make their understanding and interpretation is not an easy task (Howwar, 2013). In this regard, translation of idioms was supported in related literature as a way to develop cultural awareness skills because EFL learners, when translating an idiom from one language to another, pay more attention to cultural features and meaning of idioms (e.g., Ping, 2018; Salamah, 2015; Shojaei, 2012; Grant \& Bauer, 2004).

Although a considerable amount of related literature has been devoted to idioms and their translation in the EFL context, very little has been said about color idiom and their role in developing cultural awareness skills necessary for provide a high-quality translation of these idioms. Inspired by this scarcity of such a research in Egypt and the Arab area, the present study focused on investigating the effectiveness of a proposed training program based on idiomatic translation in developing cultural awareness skills and attitudes towards translation among non-specialist students of English at Port Said Faculty of Education.

\section{1-3 Statement of the Research Problem}

The non-specialist students of English at Port Said Faculty of Education had limited cultural awareness skills when they come across in color idioms activities, represented in their lack of adequate openness and sensitivity to other cultures, inappropriate communication to other peers from diverse cultural backgrounds, both verbally and non-verbally, and limited evaluation of their own and others' local cultures. This led to misinterpretations of the color idioms' original meanings. These aspects of weaknesses may be attributed to their inappropriate training on cultural awareness skills. Using a proposed unit based on instruction and translation of color idioms, which are cultural and social in nature, and investigating its effect on developing their cultural awareness skills and attitudes toward translation, was suggested in this research. 
Dr. Maged Mohammedain

\subsection{Research Questions}

Mainly, this study sought an answer to the following question: "What is the effectiveness of a proposed training unit on color idioms in developing cultural awareness and attitudes toward translation among the nonspecialist students of English at Port Said Faculty of Education?".

Accordingly, the following research sub-questions guided this study:

1. What are color idioms in English?

2. What are cultural awareness skills necessary for the non-specialist students of English at Port Said Faculty of Education?

3. What are the components of the proposed unit on color idioms?

4. What is the effect of teaching the proposed unit on developing cultural awareness skills among the non-specialist students of English at Port Said Faculty of Education?

5. What is the effect of teaching the proposed unit on developing attitudes toward translation among the non-specialist students of English at Port Said Faculty of Education?

\subsection{Aims}

The major aim of this research was to investigate, as carefully and precisely as possible, the effectiveness of teaching a proposed training unit on color idioms in developing cultural awareness and attitudes toward translation among the non-specialist students of English at Port Said Faculty of Education. To achieve this aim, this study tried to achieve the following objectives:

1. To highlight color idioms in English, and critical cultural awareness skills necessary for the non-specialist students of English to be developed at both professional and social levels.

2. To provide a well-controlled experiment for building and teaching a proposed unit for the development of cultural awareness skills in a way that can strengthen the link between theory and practice.

3. To suggest a series of EFL teaching materials and procedures for raising students' low levels of attitudes toward translation as a base for encouraging non-specialist students of English to pursue their language interests and keep learning the English at their own pace.

\subsection{Significance}

It was hoped that the findings of this study can contribute to:

1- Provide non-specialist students of English with a significant instructional unit to raise cultural awareness skills critical to understand similarities and differences around rules, norms among cultures, and avoid the risks of misunderstanding and miscommunication across cultures. 
Dr. Maged Mohammedain

2- Help EFL teachers recognize and identify a new methodology to help their students learn and cooperate together and openly recognize ways for conveying ideas effectively with other individuals of different cultural backgrounds.

3- Help EFL researchers take a closer look at the relationship between translation use and the cultural competence in English education classes that may enable non-specialist students of English to find effective solutions to problems they confront in communication with other individuals of different cultural backgrounds in their everyday lives.

4- Help EFL curricula developers and university policy makers organize what will be taught about idioms, cultural awareness as an issue, problem need to be addressed among non-specialist students of English, and the content to support the development of their cultural competence.

\subsection{Procedural Definitions of Terms:}

For the purposes of this research, the main terms are procedurally defined as:

1. Idiom: a common verbal phrase or expression in a fixed order that means something different to the literal meaning of its words.

2. Color Idioms: idiomatic expressions using colors beyond their apparent meanings to express varied moods and feelings.

3. Idiomatic Translation: to interpret and translate idioms mentioned in the target text.

4. Culture: a set of ideas, customs, arts, and tools that characterize the way of life of a particular group of individuals during a given period of time.

5. Cultural awareness: to be aware of, appreciate, understand, and accept the cultural similarities and differences that exist across cultures.

6. Cultural awareness Skills: a set of mental abilities required to help the non-specialist students of English at Port Said Faculty of Education to be consciousness and aware of similarities and differences across two or more civilizations.

7. Attitudes toward Translation: a set of acquired, not natural, favorable or unfavorable, behaviors shown by non-specialist students of English at Port Said Faculty of Education towards the color idiom they translate.

8. Non-specialist students of English: Undergraduate students, except students of the English department, enrolled in the second level at Port Said Faculty of Education, taking an English for non-specialists' 
Effect of a Proposed Unit on Color Idioms on Developing Cultural Awareness and Attitudes toward Translation among Non-specialist Students of English

Dr. Maged Mohammedain

course as an educational requirement in addition to their normal courses of study.

\section{Theoretical Framework}

This section serves as a summary and review of recent literature on culture, cultural awareness, relationship among language and culture, idioms as a culture- based language expression, color idioms, and the nature of idiomatic translation.

\subsection{Culture}

Culture is not an easy term to explain because it changes over time. There are some important definitions that can further understanding of the concept of culture. One of the general definitions of culture is proposed in the study of Bowman, et al., (2016) in which culture was defined as a set of values, beliefs and thought that belong to a particular society. It refers to individuals' behaviors, ideas, skills, arts, beliefs and perceptions of the surroundings worldviews. Further, the study of Nieto \& Booth (2010) defined culture as what a particular group of people constantly learn, invent, develop and pass on to other groups including acceptable and unacceptable patterns of customs, behaviors, values and traditions through varied contexts of verbal or nonverbal communication across groups.

Moreover, Javdani \& Mahboudi (2012) shared a belief that culture is divided into two main categories: (1) big $C$ : it is called visible culture including a culture's literature, classical music, architecture, historical figures, and geography, (2) little c: it is called invisible including people's every day way of thinking and behavior, traditions, practices, opinions, core valued, and attitudes. In this context, Sewell (2005) divided culture into five main categories, as follow:

(i) Culture as learned: it includes all forms of learned behaviors that pass on from one generation to another such as believes, customs, habits and myths.

(ii) Culture as institutional sphere: it assumes that culture is formed by clusters of institutional spheres such as the spheres of politics, and economy.

(iii) Culture as creativity: it assumes that culture is grown at a strong tradition.

(iv) Culture as the system of symbols: it assumes that culture as a system of symbols and meanings is influenced by a number of a demographic, geographical, and technological variables.

(v) Culture as practice: it assumes that culture practice depends on a froup of variables including willful action, power relations, and change. 
Effect of a Proposed Unit on Color Idioms on Developing Cultural Awareness and Attitudes toward Translation among Non-specialist Students of English

Dr. Maged Mohammedain

It is evident that a culture in a given society affects and is affected people's the context of living, way of thinking, thoughts and feeling, one's social relations with the other members of the society. It affects one's sense of responsibility towards others and the ability of managing social behaviors. Rogoff (2003:12) indicated that culture is changeable, and vary from one social group to another inside the one society, insisting that varied cultural practices among groups of people inside the same society does not mean that only one group's way of life is the 'right' one, and then disregarding the others. For the purposes of the current study, culture is a set of ideas, customs, arts, and tools that characterize the way of life of a particular group during a given period of time.

\subsection{Cultural Awareness}

A quick glance at related literature reveals that cultural awareness has been one of the most attractive research areas in recent decades (e.g., Kourova \& Modianos, 2013; Tomalin \& Stempleski, 2013; Lum, 2010). In related literature, there is no single definition of the concept of cultural awareness. According to Lum (2010), cultural awareness is the competence to know cultural backgrounds, issues, and relationships with conscious attention through the mind and sense. Further, the study of Nieto \& Booth (2010) asserted that cultural awareness is one's ability to communicate, understand and accept negative and positive cultural traits of others and his/ her own. Tomlinson and Masuhara (2004) looked at cultural awareness from two perspectives: (i) remarking to the totality of the way of life shared by a particular group of people with concern to characteristics, circumstances, activities, values, conventions and beliefs; and (ii) remarking to the beliefs, ideas and behaviors prevailed in a community of people who share the same capabilities, attitudes, motives, interests and targets. For the purposes of the current study, cultural awareness is to be aware of, appreciate, understand, and accept the cultural similarities and differences that exist across cultures.

According to Wunderle (2006), the process of cultural awareness is developed through five levels, as follow:

(i) Data and information: In this level, an individual collects a clear data and information from a wide range of sources about the cultural similarities and differences between two or more societies in order to assist the communication process with others from different cultural backgrounds.

(ii) Cultural consideration: In this level, an individual begins to gain an understanding of the culture, and considers the values and conventions included in it to make the communication process stronger. 
Effect of a Proposed Unit on Color Idioms on Developing Cultural Awareness and Attitudes toward Translation among Non-specialist Students of English

Dr. Maged Mohammedain

(iii) Cultural knowledge: In this level, an individual begins to use the information and cultural considerations owned in making a comparison and contrast between others' cultures and his own culture.

(iv) Cultural understanding: In this level, the individual increases his own cultural understanding through advanced training that can provide awareness in the process of thinking, the process of making a decision, and the motivating factors behind.

(v) Cultural competence: In this level, the individual focuses on planning decisions taken in certain situations.

Past research studies agree that possessing a satisfactory level of cultural awareness provide students with a wide range of benefit such as understanding and respecting the way of life of others. Tomalin \& Stempleski (2013) indicated that cultural awareness helps students to be more comprehending and tolerant of varies customs, ideas and behaviors that are different from their own. Added to this, Kourova \& Modianos (2013) believed that cultural awareness helps students not only to understand and appreciate similarities and differences with other people of different cultural backgrounds, but also is an effective tool to bring students closer to the richness their own local culture. Furthermore, the study of Shemshadsara (2012) indicated that increased cultural awareness and positive attitudes towards cross-cultural differences prevents possible conflicts that may arise among students as a result of misinterpretations, stereotypes, and ethnocentrism as well as prejudice.

\subsection{Integrating Cultural Awareness in Language Education}

Atay, et al., (2009) concluded that the relation between language and culture is embodied in the individual person, thought to be a thinker, a creator, and a transmitter of culture, who uses the language for communication with others. A quick glance at related literature reveals that relationship between language and cultural awareness is inseparable. Integration of cultural awareness in the foreign language learning and teaching was inevitably recommended by a number of researchers. To begin with, Cakir (2006) argued that cultural awareness should be taught in the language classroom through greetings, expressions, dialogues, and everything students hear inside the classroom to help students grasp the differences between their own culture and other cultures. Moreover, Abdzadeh (2017) concluded that the integration of cultural awareness, alongside with other cultural factors, into the EFL classrooms is critical to help EFL students achieve a better understanding of the English language and to ensure their capabilities of successful cross-cultural communication in real situations. 
Effect of a Proposed Unit on Color Idioms on Developing Cultural Awareness and Attitudes toward Translation among Non-specialist Students of English

Dr. Maged Mohammedain

Additionally, Zhao (2009) provided the following suggestions to foster EFL students' cross-cultural awareness: (1) to get EFL learners acquainted with the customs, habits, and life-styles generally accepted in the English speaking countries; (2) to get EFL learners acquainted with the effect of the interaction between language and specific social variables on individual's way of thinking, speech and act; and (3) to raise EFL students' ability to objectively assess other cultures. In a more recent work conducted by Barany (2016) shared a belief that cultural awareness should be integrated into the teaching of all the four language skills in order to help language learners speak the target language in culturally appropriate ways.

\subsection{An Idiom as a Culture-based Language Expression}

Idioms are found in every culture. In addition to its role as a linguistic representation of a certain language, they express a system of habits, traditions, customs, lifestyles, values, conventions of the society they belong to. Related studies agree that every idiom carry a cultural specific meaning which cannot be interpreted easily away from its original culture. Yang (2010:148) shared a belief that the geographical location of a given culture significantly affects the formation of an idiom. Guineng (2012:109) stressed that there are three factors which influence idioms as cultural-based language expressions:

(i) Geographical location: most idioms that appear in a culture which is famous for sailing, agriculture or manufacture would be related to these specific geographic elements;

(ii) Historical background: historical events, customs of a particular culture, the type of country government, or the presence of royal families are reflected in the idiom used inside the society; and

(iii) Religion: religious views of a culture tend also to appear in idioms.

Broadly speaking, idioms are defined, according to the study of Liu (2012) as linguistic components providing information in regard to the conceptual system of a specific society. According to Abel (2003), an idiom is a fixed expression which it is difficult to be comprehended from its singular wordsAdded to this, Ping (2018), states that every idiom consists of the following features:

- The whole unit of an idiom possesses one meaning;

- It is impossible to understand the meaning from its separate words;

- There is an inner interdependence among the idiom words;

- Lexical content is always the same;

- Idioms are constant elements of everyday speech;

- The presence of particular environment. 
Effect of a Proposed Unit on Color Idioms on Developing Cultural Awareness and Attitudes toward Translation among Non-specialist Students of English

Dr. Maged Mohammedain

It is well known that idioms are used unconsciously in everyday life. According to Rezaeifard \& Chalak (2017), the difficulty of providing suitable equivalents causes a lot of misunderstandings and makes dealing with idioms a challenging task activity for EFL learners. Additionally, Liu (2012) indicated that idioms are culture-specific expressions, and using them with non-native language speakers without suitable equivalents can cause communication breakdowns. Examples of common English idioms that express both linguistic and cultural representations may include "Burning the midnight oil", a cultural idiomatic expression appeared in the period before the advent of electric lighting, meaning to keep working late into the night.

\subsection{Color Idioms}

Words denoting colors are used heavily in idiomatic expressions, either negatively or positively, representing cultural backgrounds and history of the language. Color idioms is a type of idiomatic expressions that is both artistic and popular, heard and read many times, and in which culture plays an important role in their interpretation (Oualif, 2017). Added to this, according to Dumitrascu (2007), a color idiom is an idiomatic expression that:

- Is comprised of at least one word referring to a certain color.

- Has a hidden meaning, and the color itself is not directly implied.

Hasan, et al., (2011) asserted that interpretation of color idioms varies widely by different nations, and can be influenced by: (i) cultural associations, (ii) political and historical associations, and (iii) religious and mythical associations. Both of English and Arabic share the phenomenon of color idioms. For example, Black is a popular color used in English idioms to give the sense of darkness as in the 'black market' and the 'blacklist' idioms. On the contrary, black is often contrasted with white in numerous other domains as in the idiom "Put something down in black and white", meaning to write something down on a paper for purposes of confirmation.

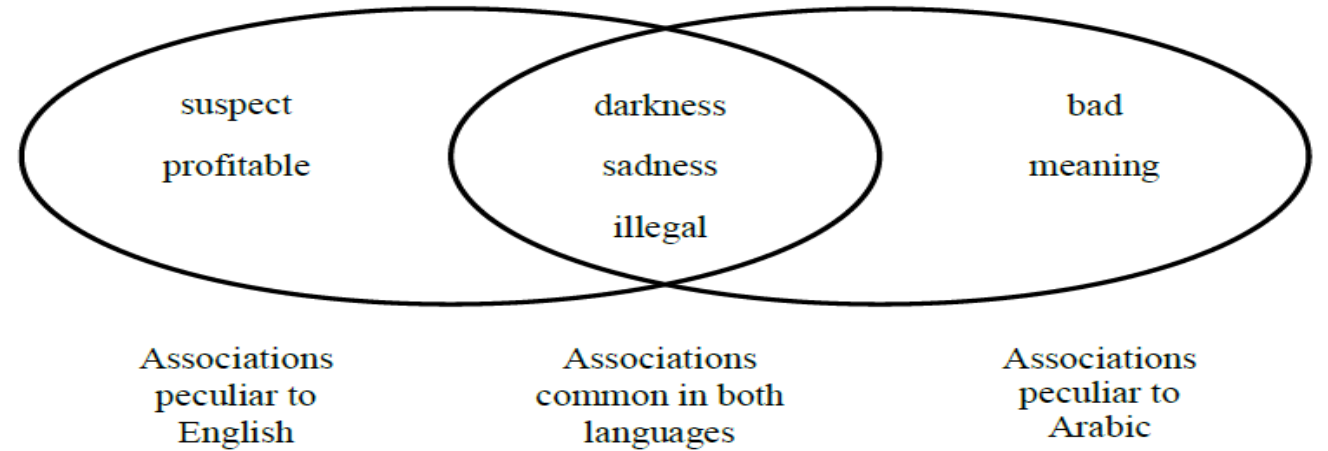

Figure 2.1: Key associations of the color black in English and Arabic

(Source: Alotaibii, 2020:104) 
Effect of a Proposed Unit on Color Idioms on Developing Cultural Awareness and Attitudes toward Translation among Non-specialist Students of English

Dr. Maged Mohammedain

Arabic use a wide range of color idioms, as in 'بيضت وشي' meaning to do a favor, 'white day', meaning to have a good day, or 'white heart', meaning someone is kind. Table (2.1) presents a selection of color idioms in Arabic and their translations into English.

Table (2.1): A Selection of color idioms in Arabic and their translations into English

\begin{tabular}{|c|c|c|}
\hline Color & $\begin{array}{lll}\text { Color idioms in } \\
\text { Arabic }\end{array}$ & Translation in English \\
\hline \multirow{4}{*}{ Black } & ق قلبه اسود & He is mean/evil \\
\hline & يوم اسود & A bad day \\
\hline & السوق السوداء & Black market (the same as in Arabic) \\
\hline & يا أبيض يا أسود & A very strict person with a clear vision \\
\hline \multirow{3}{*}{ Red } & طلعله العين الحمراء & Being strict or angry with someone \\
\hline & ل & Very angry \\
\hline & خط أحمر & Very important or forbidden \\
\hline \multirow{3}{*}{ Yellow } & ابتسم ابتسامة صفراء & Not giving a true smile \\
\hline & و مشه أصفر & Being ill \\
\hline & وشهه صفرً وخضرَ & Being shocked or scared \\
\hline
\end{tabular}

\subsection{Idiomatic Translation}

Translation is generally defined as the process of conveying the meanings and content of a source text, as accurately as possible, to an equivalent target text. Today, translation remains paramount in improving and aiding everyday communication among people and ensuring comprehension of other cultures. Nida (1964, cited in House, 2015) claimed that without translation, much would have been missed since translation is a bridge between different cultures, a mediator to overcome shared lingua-cultural barriers.

Related research studies agree translation of idioms that have cultural bound meanings might be problematic. Tran (2012) indicated the importance of considering culture in the process of translation, arguing that translators have to acquire adequate level of cultural knowledge to make translation of cultural loaded idioms easy. Additionally, Violetta (2015) stressed that, when translating cultural specific idioms, finding the suitable equivalence in the target language may be a challenging task due to cultural

\begin{tabular}{|c|c|c|}
\hline هبلة كلية التزبية - جاهعة بوررسعيد & $\wedge \wedge 7$ & 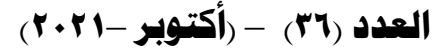 \\
\hline
\end{tabular}


Dr. Maged Mohammedain

gaps. According to Al Zahrani (2018), difficulties in translating English idioms into Arabic can be divided into the following:

1- Non-equivalence in Translation: some English idioms have not an equivalent in Arabic, and only can be expressed using one word or phrase. For example, the English idiom "To feel blue" has not an Arabic equivalent. However, sometimes it is translated as (مأزق) or (كرية).

2- Cultural Problems: former knowledge on the cultural specificity of idioms is significant. For example, "as white as snow" is an English idiom translated as "white as cotton or milk" into Arabic because the Arab countries are not familiar with snow.

3- Expressions with Two Meanings: sometimes, an English idiom holds two meanings, one is literal, and the other is idiomatic. This happens mostly with idioms based on a physical image, such as the idiom $a$ slap on the face. This idiom has two meanings. The first is literal, that is to insult someone, whereas

Furthermore, Nolan (2005) concluded that lack of an equivalent idiom in the target language that corresponds to the source idiom in both form and meaning poses a big problem for every translator. Likewise, Zarei \& Pour (2013) concluded that fixed word orders of idioms, non-literal meanings, as well as the special word grouping of some idioms are the primary reasons for the challenges EFL students confront when dealing with idioms.

In spite of the above-mentioned idiomatic translation difficulties, some translation strategies were identified in related research to produce a seemingly natural translation of idioms. Al-Shawi \& Mahadi (2012) proposed the following strategies to avoid difficulties in translating English idioms into Arabic:

1. Using a parallel Arabic idiom: this strategy is used to ensure conveying the same meaning as that of source language. For example, the English idiom First with the first is preferably translated into Arabic as (أولاً بأول).

2. Using similar meaning but dissimilar form: it is to convey the intended meaning while presenting the same original effect. For example, the English idiom Jack of all trades but master of non" is preferably translated into Arabic as (سبع صنايع والبخت ضايع).

3. Paraphrasing the idiom: it is to convey the implied meaning of the idiom expression without maintaining its idiomatic quality. Examples may include (Keep his finger on the pulse) to be translated as ( يراقب (الوضع بدقة 
Effect of a Proposed Unit on Color Idioms on Developing Cultural Awareness and Attitudes toward Translation among Non-specialist Students of English

Dr. Maged Mohammedain

To conclude, research into idiomatic translation indicated that it is a challenging area and it is important to employ useful skills and strategies in order to translate an idiom into another language accurately without losing their actual meaning.

\subsection{Commentary}

The main theoretical focus of this study was on reviewing related literature on culture, cultural awareness, relationship among language and culture, idioms as a culture- based language expression, color idioms, and the nature of idiomatic translation. The aforementioned related studies made the researcher convinced that language is one of the main social carriers of culture. Idioms, one of the prevailed language expressions with distinctive national cultural features, are often used regularly by language learners in normal communications and worth noting in the context of cultural awareness development. The meaning of idioms was believed in related literature to be arbitrary, and accurate translation is highly required.

Added to this, despite their high frequency of use, limited research has been done on how to teach and learn color idioms, although viewed by many researchers as a central element to the English language. Also, the researcher concluded that although non-specialist students of English, can make use of translation of color idiom in developing their cultural awareness as translation helps them to be sensitive to cultural differences. Based upon, the researcher found that it is important to provide nonspecialist students of English a proposed instructional unit on color idioms, and to investigate its effectiveness on the development of cultural awareness skills and attitudes toward translation.

\section{Methodology}

This part declares the research design, hypotheses, sampling, instruments, and procedures of data collection and analysis followed throughout the current study.

\subsection{Design}

This study has employed two methods. First and foremost, a descriptive analytical method was used to investigate cultural awareness skills and attitudes toward translation among non-specialist students of English. The second one was an experimental method with a one-group pretestposttest design in which the dependent variables (cultural awareness skills and attitudes toward translation) are measured once before the independent variable (the proposed unit based on translation of color idioms in English) is implemented and once after it is implemented.

\subsection{Hypotheses}

This study attempted to verify the following research hypotheses: 
Effect of a Proposed Unit on Color Idioms on Developing Cultural Awareness and Attitudes toward Translation among Non-specialist Students of English

Dr. Maged Mohammedain

Hypothesis One: There is a statistically significant difference between the mean scores of the experimental group students in both the pre-application and post- application of the scale on cultural awareness skills, in favor of the post applications.

Hypothesis Two: There is a statistically significant difference between the mean scores of the experimental group students in the pre-application and post- application of the scale on their attitudes toward translation, in favor of the post applications.

Hypothesis Three: The proposed unit on color idioms is statistically significant in developing cultural awareness skills and attitudes toward translation of the experimental group students.

\subsection{Sampling}

The population contributed to this study were (76) non-specialist students of English, enrolled in the second level of all departments except the English Department, in the general and basic divisions, at Port Said faculty of education in the first semester of the academic year (2020-2021). For the purposes of the current study, the participating sample included only (22) non-specialist students of English, randomly assigned as the experimental group. All participants were Arabic native speakers. There ages ranged from (19.1 / 20.4). The one-group experimental design was necessary: (i) due to the researcher's limited time, (ii) in order to maintain a large focus on the participating sample, and (iii) to ensure that the participating group as a whole was receiving the best possible learning experiences.

\subsection{Instruments}

The instruments used in this study were;

1- A scale on participants' cultural awareness skills.

2- A scale on participants' attitudes toward translation.

All instruments used were written and edited in the English language. To make data collection easier, all of the above-mentioned instruments were prepared and implemented by the researcher himself and presented to the participating sample in a paper format.

Before the treatment, a pre-application of the two scales was implemented. Later, the proposed unit based on translation of color idioms in English was instructed as an extracurricular activity for the experimental group students. It took five weeks. In every week, students were receiving two sessions, each lasted for two hours of training on color idioms and completed different translation activities. When completed, all students in the experimental group were given a post-application of the two scales, which both were the same as in the pre-applications. Their results in the pre-applications and post- applications were collected and contrasted to each other in order to check the progress of the participating sample owing to the use of the proposed unit. 
Effect of a Proposed Unit on Color Idioms on Developing Cultural Awareness and Attitudes toward Translation among Non-specialist Students of English

Dr. Maged Mohammedain

\subsubsection{The Pre-Post Scale on Cultural Awareness Skills.}

With concern to the study problem, the scale on participants' cultural awareness skills was prepared by the researcher, aiming to measure the development of these skills among the study participants owing to the use of the proposed unit based on translation of color idioms in English.

Further, the scale was prepared with concern to varied resources, including (i) previous related studies such as Farooq, et al., (2018), Abdzadeh (2017), Abushihab (2016), Bowman, et al., (2016), Alsamani (2014), Lawson-Davenport (2014), Kourova \& Modianos (2013), Tomalin \& Stempleski (2013), Byram (2012), and Shemshadsara (2012). Adapting one of the scales proposed in previous related studies was not preferable due to many factors outside of the researcher's control, including inapplicability in the local Egyptian educational environment, extensive time required to fill in the scale, variation of the target population, scale instructions' lack of clarity, exaggerated number of items, and inadequate sequence of items. Added to previous related studies, the suggestions and pieces of advice presented a qualified group of by professors and assistant professors, specialized in curricula \& instruction, TEFL and Educational Psychology had actually helped the researcher form better items. Additionally, the researcher's own personal expertise as an EFL language instructor influenced forming the final wording of the scale items in an easy-tounderstand and satisfactory way.

The scale generally consisted of two parts. The first part was devoted to gather information about the participants' background information including an introduction to define it's the scale goal, general instructions on application method, and how a participant can record responses and data. In this regard, this part asked every participant to provide an informed consent to fill in the scale. Additionally, this part made clear to the participating sample that it is not allowed to reveal any participant's name or domicile in order to safeguard their anonymity.

The second part provided the items designed to elicit participants' reactions toward reflective thinking skills. The scale items were distributed as a 4-point Likert scale (Every Time / Often / Rarely / Never). The degrees assigned were $(4 / 3 / 2 / 1)$ respectively. The initial form of the scale included (67) items, calculated as a whole to obtain the total score of each participant, ranging between $(67 / 268)$ degrees. A higher score implies a high level of cultural awareness skills of non-specialist students of English at Port Said Faculty of Education, and vice versa.

In the light of the findings of previous related studies, the initial form of the scale items was distributed into six dimensions as follow:

1. Communicative competence: capability of using verbal and nonverbal responses to suit the cultural context. 
Effect of a Proposed Unit on Color Idioms on Developing Cultural Awareness and Attitudes toward Translation among Non-specialist Students of English

Dr. Maged Mohammedain

2. Respect for Cultural Differences: understanding and demonstrating respect for culturally specific behaviors of others with different cultural and cognitive styles.

3. Interaction Confidence: to believe in cultural difference between own culture and other cultures, and to accept the realities concerning it.

4. Interaction Enjoyment: feelings of enjoyment and satisfaction in a particular cultural context.

5. Synergistic competence: To understand that cultural differences can be both problematic and beneficial, and to be open to new alternatives/solutions.

6. Participatory competence: to derive a culture with a shared values with others.

To help the scale provide richer answers to the research questions, significant aspects were taken into consideration in the formulation and order of the scale items, including: (i) to clearly explain the way of answering, (ii) the items were carefully and precisely worded, (iii) to use proper and simple items to avoid misunderstanding or potential confusion, and (iv) to arrange the items in a reasonable sequence.

To ensure the scale validity, its initial form, consisting of (67) items of six dimensions, was submitted to an expert panel formed of (9) professors and assistant professors specialized in the fields of TEFL, Curricula \& Instruction, and Educational Psychology. Such a procedure was critical and meaningful to ensure that the scale is of high quality, the items are reliably observed and evaluated, and the scale is targeted to measure exactly and properly what is intended. The percentages agreement among the panel members ranged $(87.9 \%-100 \%)$ on all the scale items, suggesting that the scale items have relatively high validity. However, they provided some suggestions and modifications concerning the scale length, items vagueness and appropriateness. All modifications suggested by the panel members were made. Table 3.1 shows the distribution of the scale items included in the final form.

Table 3.1: Distribution of Items in the Scale Final Form

\begin{tabular}{|c|c|c|c|}
\hline Dimensions of Skills & $\begin{array}{c}\text { Total } \\
\text { Items }\end{array}$ & $\begin{array}{c}\text { Relative } \\
\text { Weights }\end{array}$ & Items \\
\hline $\begin{array}{c}\text { Communicative } \\
\text { competence }\end{array}$ & 13 & 19.5 & $1 / 2 / 14 / 23 / 29 / 30 / 47 / 48 / 53 / 54 / 65 / 66 / 67$ \\
\hline $\begin{array}{c}\text { Respect for Cultural } \\
\text { Differences }\end{array}$ & 10 & 14.9 & $7 / 8 / 17 / 21 / 35 / 36 / 43 / 44 / 59 / 60$ \\
\hline $\begin{array}{c}\text { Interaction } \\
\text { Confidence }\end{array}$ & 12 & 17.9 & $\mathbf{5 / 6 / 1 6 / 2 2 / 2 5 / 2 6 / 3 7 / 3 8 / 4 9 / 5 0 / 6 1 / 6 2}$ \\
\hline
\end{tabular}


Effect of a Proposed Unit on Color Idioms on Developing Cultural Awareness and Attitudes toward Translation among Non-specialist Students of English

Dr. Maged Mohammedain

\begin{tabular}{|c|c|c|c|}
\hline \hline $\begin{array}{c}\text { Interaction } \\
\text { Enjoyment }\end{array}$ & 10 & 14.9 & $9 / 10 / 15 / 24 / 31 / 32 / 45 / 46 / 55 / 56$ \\
\hline $\begin{array}{c}\text { Synergistic } \\
\text { competence }\end{array}$ & 10 & 14.9 & $3 / 4 / 18 / 19 / 33 / 34 / 41 / 42 / 51 / 52$ \\
\hline $\begin{array}{c}\text { Participatory } \\
\text { competence }\end{array}$ & 12 & 17.9 & $11 / 12 / 13 / 20 / 27 / 28 / 39 / 40 / 57 / 58 / 63 / 64$ \\
\hline Total & 67 & $\% 100$ & 67 ITEMS \\
\hline
\end{tabular}

The scale was piloted with a group $(\mathrm{N}=20)$ of non-specialist undergraduate English students at Port Said faculty of education similar to and out of those participating in the study. The scale had a Cronbach reliability index of 0.85 ., implying a relatively high reliability. Regarding the scale internal consistency, all the correlation coefficients were significant at $(\alpha \leq 0.01)$ level, ranging from $(0.34)$ to $(0.89)$, implying a relatively high internal consistency.

As for the items' difficulty and discrimination, the computed correlation coefficients ranged from $(0.28)$ to $(0.80)$, implying the scale is free of very difficult or very easy items, and able to distinguish students of weak, moderate and strong levels of cognitive achievement. Additionally, (70) minutes was found as a suitable time for administering the scale, in addition to other (5) minutes for reading the scale instructions. Appendix (B) presents the final form of the scale.

\subsubsection{The Pre-Post Scale on Participants' Attitudes toward translation.}

The aim of this scale was to identify the development of non-specialist students of English' attitudes toward translation among the study participants owing to the use of the proposed unit based on translation of color idioms in English. Investigating such attitudes is critical to recognize the state of English education for non-specialist students of English, as well as to predict students' future choices to act accordingly.

In this regard, this scale was prepared with concern to the scales proposed in past literature, including Habeeb, Ahmed \& Abu el-Reesh (2016), Mekheimer (2012), El-Tantawi (2011), Dahroug (2007), and Teleiba (2004). Although these related studies have made great contributions in this concern, it was preferred to develop a new scale for the fear of their scales' unsuitability for application in a local Egyptian educational environment. Additionally, some colleagues specialized in the fields of TEFL and Educational Psychology at Port Said faculty of education provided considerable suggestions and comments that were very helpful.

In general, the scale was divided into two parts in line with the current research purposes. The first part required participants to provide diverse background information, such as their names (optional), gender, age, and 
Dr. Maged Mohammedain

so forth. The second part provided the study participants items designed to elicit their perspectives regarding their profession as EFL future potential teachers.

The initial proposed scale included a series of (60) items. A Likert scale with 2 points (Agree/Disagree) was used. This type is the simplest form of Likert scales, providing no neutral options, was necessary to help make the scale easy and not complicated, and avoid leaving the participants unsure of how accurately to answer the items. The degrees assigned were (2/1) respectively, calculated as a whole to obtain the total score of each participant, ranging between $(60 / 120)$ degrees. A higher score indicates a high level of attitude towards the English subject among for non-specialist students, and vice versa. The aim of the proposed scale was to evaluate the level of four main dimensions of non-specialist students' attitudes toward translation, as follow:

1- Personal perspective of translation significance,

2- Personal perspective of interest in translation,

3- Personal perspective of translation instruction, and

4- Personal estimation of translation capabilities.

To help the scale achieve its intended purposes, the following were considered: (1) to clearly explain the way of answering, (2) the items were carefully and precisely worded, (3) to use proper items to avoid misunderstanding or potential confusion, and (4) to arrange the items in a reasonable sequence. To help establish the scale face and content validity, the initial form, consisting of (60) items of four dimensions, was reviewed by an expert panel of nine education experts in the fields of TEFL, Curricula \& Instruction, and Educational Psychology in terms of items' quality, clarity, preciseness, sequence, suitableness, and potential to measure exactly and properly what is intended. The percentages agreement among the panel members ranged $(86.4 \%-100 \%)$ on all the scale items, implying that the scale items have relatively high validity. According to the panel's feedback, views and suggestions, the scale was revised, refined and modified to form its final form with 57 items (as three items were deleted), with four dimensions, and a score ranging between (57/114) degrees of each participant, as shown in table (3.2). 
Effect of a Proposed Unit on Color Idioms on Developing Cultural Awareness and Attitudes toward Translation among Non-specialist Students of English

Dr. Maged Mohammedain

\begin{tabular}{|c|c|c|}
\hline \hline \multicolumn{2}{|c|}{ Table 3.2: Distribution of Items in the Scale Final Form } \\
\hline Dimensions of Attitudes & $\begin{array}{l}\text { Total of } \\
\text { Items }\end{array}$ & Items \\
\hline translation significance & 15 & $\begin{array}{c}1-8-9-15-16-22-23-30-31-35-44-45- \\
49-50-53\end{array}$ \\
\hline interest in translation & 14 & $\begin{array}{c}4-5-12-13-19-20-26-27-39-40-42- \\
43-47-48\end{array}$ \\
\hline translation instruction & 14 & $\begin{array}{c}2-3-17-18-24-25-32-33-36-37-41- \\
46-51-52\end{array}$ \\
\hline translation capabilities & 14 & $\begin{array}{c}6-7-10-11-14-21-28-29-34-38-54- \\
55-56-57\end{array}$ \\
\hline
\end{tabular}

Furthermore, the scale was piloted with a group $(\mathrm{N}=20)$ of non-specialist undergraduate English students at Port Said faculty of education similar to and out of those participating in the study. The test had a Cronbach reliability index of 0.87 ., implying a relatively high reliability. Regarding the scale internal consistency, all the correlation coefficients were significant at $(\alpha \leq 0.01)$ level, ranging from $(0.16)$ to $(0.80)$, implying a relatively high internal consistency.

As for the items' difficulty and discrimination, the computed correlation coefficients ranged from $(0.24)$ to $(0.88)$, implying the scale is free of very difficult or very easy questions, and able to distinguish students of weak, moderate and strong levels of cognitive achievement. Additionally, (55) minutes was found as a suitable time for administering the scale, in addition to other (5) minutes for reading the scale instructions. Appendix (C) presents the final form of the scale.

3.5. The Proposed Unit based upon on Translation of Color Idioms in English.

The proposed unit based on translation of color idioms in English was designed to cover significant areas in instruction and translation of color idioms in English that represent values, beliefs, customs and social traditions prevailed in the western culture, and may / or may not have equivalents in the Arabic culture, in a way that ensures providing the participating sample with the best EFL learning experiences that can sharpen their culture awareness skills and increase their positive attitudes toward translation. This design stood on objectives of the present study, the nature of the research population, and the findings of related research studies such as Alotaibii (2020), Farooq, et al., (2018), Abdzadeh (2017), Abushihab (2016), Bowman, et al., (2016), Alsamani (2014), Salim \& Mehavesh (2013), Al-Adaileh (2012), Guineg (2012), Liu (2012), Xin (2012), Ahmadi \& Ketabi (2011), Dordevic (2009), and Chielens (2007). 
Effect of a Proposed Unit on Color Idioms on Developing Cultural Awareness and Attitudes toward Translation among Non-specialist Students of English

Dr. Maged Mohammedain

Appendix (D) presents a detailed explanation of the proposed unit design.

To ensure face and content validity of the proposed unit, an expert panel including ( $\wedge$ ) experts in the fields of TEFL, Curricula \& Instruction, Translation and Educational Psychology reviewed the proposed unit based on translation of color idioms in English in terms of quality, preciseness, sequence, and potential to attain its intended objectives. The expert panel assured the overall suitableness and the relevancy of the proposed unit components.

In order to capitalize the proposed unit outcomes, the following considerations were taken into account during implementation:

1- To balance the proposed unit objectives and students' educational needs.

2- To review and recognize relevant and similar units, training programs and courses in order to get an adequate knowledge of effective instructional techniques to help students engage in.

3- To possess an adequate knowledge of the rules and structural patterns of varied the culture competence and methods of development in language education classrooms.

4- To possess an adequate knowledge of various personally effective ways to meet the individual differences among students and help them translate color idioms accurately and creatively.

5- To design and carry out the translation tasks and activities in an effective way to ensure that the students, especially demotivated ones, are actively participating.

6- To devote adequate time for instruction, group work and feedback.

\subsection{Study Procedures}

The consequent procedures were followed to investigate the effect of the proposed unit based on translation of color idioms in English on developing cultural awareness skills and attitudes toward translation among nonspecialist students of English at Port Said Faculty of Education:

I. Before starting the actual data collection process, it was necessary to carry out a pilot survey $(\mathrm{N}=20)$ to ensure validity, internal consistency, reliability of the instruments in order to state that their items are clearly articulated, relevant, straightforward and comprehensive.

II. The target sample was one group randomly selected and assigned as the experimental group $(\mathrm{N}=22)$, and treated with proposed unit based on the translation of color idioms in English.

III. The two scales on participants' cultural awareness skills and their attitudes toward translation were pre-applied on the experimental 
Effect of a Proposed Unit on Color Idioms on Developing Cultural Awareness and Attitudes toward Translation among Non-specialist Students of English

Dr. Maged Mohammedain

group. The mean scores, standard deviations and $T$. value in the preapplication of the instruments, were computed.

IV. The proposed unit based upon the translation of color idioms in English was instructed for (10) sessions, administered for (5) weeks on the experimental group in the first semester of the academic year 2020 / 2021. Appendix (D) includes a detailed description of sequence of these sessions. In this regard, the following aspects were considered by the researcher during the implementation of the proposed training program:

1- An overview of the instruments, objectives and content of the proposed unit was provided to the trainees.

2- A printed copy of the unit contents and the trainee handout was presented to each trainee.

3- Getting trainees acquainted with the translation activities and tasks was considered.

4- The program timetable set was respected.

5- The scheduled sequence of the proposed unit contents, tasks and activities was abided by the researcher.

6- A theoretical analysis of the targeted cultural awareness skills and attitudes toward translations was provided to trainees.

7- A sequence of instructions on the implementation of activities, tasks and drills was delivered to trainees.

8- Effective presentations in PowerPoint and video clips (if necessary) were used to display important information and tips.

V. The two scales on participants' cultural awareness skills and their attitudes toward translation were post-applied on the experimental group. The mean scores, standard deviations and $T$. value were computed.

VI. An accurate and appropriate data analysis of the findings was carried out using SPSS.V22.0.

\section{Findings and Conclusion}

This part discusses the study findings, significance, implications for EFL teaching practice, recommendations and suggestions for future research.

\subsection{Findings and Discussions}

The following findings of are outlined in accordance with the research hypotheses:

\subsubsection{Results related to the First Hypothesis:}

The first hypothesis states, "There is a statistically significant difference between the mean scores of the experimental group students in both the pre-application and post- application of the scale on cultural awareness 
Effect of a Proposed Unit on Color Idioms on Developing Cultural Awareness and Attitudes toward Translation among Non-specialist Students of English

Dr. Maged Mohammedain

skills, in favor of the post applications". To verify such a hypothesis, the mean scores, standard deviations and $T$. value of the experimental group students in the pre-application and post- application of the scale on cultural awareness skills were computed using Paired T. Test, as shown in table (4.1).

Table (4.1): Mean scores, standard deviations and T. value of the experimental group students in the pre-application and post- application of scales on cultural awareness skills.

\begin{tabular}{|c|c|c|c|c|c|c|c|c|}
\hline Variable & $\begin{array}{c}\text { Applicatio } \\
n\end{array}$ & N. & $\begin{array}{c}\text { Mean } \\
\mathbf{s}\end{array}$ & $\begin{array}{l}\text { St. } \\
\text { Dev. }\end{array}$ & $\mathbf{F}$ & $\begin{array}{c}\text { T. } \\
\text { Value }\end{array}$ & Level & Sig. \\
\hline \multirow{2}{*}{$\begin{array}{c}\text { cultural } \\
\text { awareness } \\
\text { skills }\end{array}$} & Pre- & 22 & 75.15 & 5.51 & 21 & \multirow[t]{2}{*}{82.30} & \multirow[t]{2}{*}{0.01} & \multirow{2}{*}{$\begin{array}{c}\text { Statistica } \\
\text { lly } \\
\text { Significa } \\
\text { nt }\end{array}$} \\
\hline & Post- & 22 & $\begin{array}{c}172.1 \\
1\end{array}$ & 3.19 & 21 & & & \\
\hline
\end{tabular}

It is evident from the table above that the values of " $T$ " are statistically significant at the level of 0.01 , where $T$. value was 82.30 , indicating a statistically significant difference between the mean scores of the experimental group students in the pre-application and post- application of the scale on cultural awareness skills, in favor of the post applications. Thus, the first hypothesis is verified.

The above finding corroborates the findings of other related research studies that investigated the issue of the relationship between idioms and the cultural competence and indicated the possible contribution of teaching color idioms as a tool for the development of cultural awareness skills, including the findings of Farooq, et al., (2018), Abdzadeh (2017), Abushihab (2016), Bowman, et al., (2016), Alsamani (2014), Lawson-Davenport (2014), Kourova \& Modianos (2013), Tomalin \& Stempleski (2013), Byram (2012), Shemshadsara (2012), and Ahmadi \& Ketabi (2011). These aforementioned studies shared a belief that instruction of idiomatic expressions, including color idioms, can provide the foreign language learners help to deal successfully with their lack of knowledge of cultural and historical contexts.

A possible interpretation given to explain this finding might be that the proposed unit on color idioms has a significant role in enhancing the close link between idioms and the cultural competence of language learners. To accurately interpret and adequately understand idioms, involving color ones, language learners have to know the culture where these idioms are used, or at least their origins, either historical, social or even religious ones. Another possible interpretation might be that the activities, materials, resources and active training environment created while teaching the proposed unit based on color idioms has helped the trainees acquire the actual cultural awareness skills they need. 
Effect of a Proposed Unit on Color Idioms on Developing Cultural Awareness and Attitudes toward Translation among Non-specialist Students of English

Dr. Maged Mohammedain

\subsubsection{Results related to the Second Hypothesis:}

The second hypothesis states, "There is a statistically significant difference between the mean scores of the experimental group students in the pre-application and post- application of the scale on their attitudes toward translation, in favor of the post applications". To verify such a hypothesis, the mean scores, standard deviations and $T$. value of the experimental group students in the pre-application and post- application of the scale on attitudes toward translation were computed, as shown in table (4.2).

Table (4.2): Mean scores, standard deviations and $T$. value of the experimental group students in the pre-application and post- application of scales on attitudes toward translation.

\begin{tabular}{|c|c|c|c|c|c|c|c|c|}
\hline Variable & $\begin{array}{c}\text { Applicati } \\
\text { on }\end{array}$ & N. & $\begin{array}{c}\text { Mea } \\
\text { ns }\end{array}$ & $\begin{array}{l}\text { St. } \\
\text { Dev. }\end{array}$ & $\mathbf{F}$ & $\begin{array}{c}\text { T. } \\
\text { Value }\end{array}$ & Level & Sig. \\
\hline \multirow{2}{*}{$\begin{array}{l}\text { attitudes } \\
\text { toward } \\
\text { translation }\end{array}$} & Pre- & 22 & 40.33 & 3.55 & 21 & \multirow[t]{2}{*}{37.44} & \multirow[t]{2}{*}{0.01} & \multirow{2}{*}{$\begin{array}{c}\text { Statistic } \\
\text { ally } \\
\text { Significa } \\
\text { nt }\end{array}$} \\
\hline & Post- & 22 & $\begin{array}{c}100.5 \\
5\end{array}$ & 2.11 & 21 & & & \\
\hline
\end{tabular}

It is evident from the table above that the values of " $T$ " are statistically significant at the level of 0.01 , where $T$. value was 37.44 , indicating a statistically significant difference between the mean scores of the experimental group students in the pre-application and post- application of the scale on attitudes toward translation, in favor of the post applications. Thus, the second hypothesis is verified.

The above finding corroborates the findings of other related research studies that investigated the issue of translating idiomatic expressions in general, and color idiomatic expressions in particular, and its usual role in meeting some difficulties that are hard to overcome without translation, including Habeeb, Ahmed \& Abu el-Reesh (2016), Mekheimer (2012), ElTantawi (2011), Dahroug (2007), and Teleiba (2004). These aforementioned studies recognized that translation as a bridge to overcome communication barriers between different cultures. Translation presents a solution to the problem of "equivalent culture meaning" of a given idiom.

A possible interpretation of this finding might be that the proposed unit has included authentic materials that facilitated class interactions and communication. Additionally, the included tasks of, problem-solving activities, frequent quizzes, and step-by-step feedback encouraged deeper learning and understanding of the participating sample, leading them to feel more in control of their own learning. A third possible interpretation might be that the proposed unit has emphasized an individual's interest to complete translation tasks, resulting in greater confidence. 
Effect of a Proposed Unit on Color Idioms on Developing Cultural Awareness and Attitudes toward Translation among Non-specialist Students of English

Dr. Maged Mohammedain

\subsubsection{Results related to the Third Hypothesis:}

The third hypothesis states, "The proposed unit on color idioms is statistically significant in developing cultural awareness skills and attitudes toward translation of the experimental group students". To verify such a hypothesis, Blake Modified Gain Ratio was used to recognize the proposed unit effectiveness in developing the intended cultural awareness skills and attitudes toward translation of the experimental group students, as shown in Table (4.3).

Table (4.3): Results of Blake Modified Gain Ratio.

\begin{tabular}{|c|c|c|c|c|}
\hline Instrument & $\begin{array}{l}\text { Pre-Application } \\
\text { Mean scores }\end{array}$ & $\begin{array}{l}\text { Post-Application } \\
\text { Mean scores }\end{array}$ & $\begin{array}{l}\text { Gain } \\
\text { Ratio }\end{array}$ & Sig. \\
\hline Skills & $\mathbf{7 5 . 1 5}$ & $\mathbf{1 7 2 . 1 1}$ & 1.25 & Significant \\
\hline Attitudes & $\mathbf{4 0 . 3 3}$ & $\mathbf{1 0 0 . 5 5}$ & 1.33 & Significant \\
\hline
\end{tabular}

Table (4.3) indicates the effectiveness of the proposed unit based on color idioms in developing the intended cultural awareness skills of non-specialist students of English at Port Said Faculty of Education. Data analysis resulted that mean scores were (172.11) for the experimental group. Using the Blake Modified Gain Ratio revealed that gain ratio was (1.25), a value larger than (0.05) indicating that the effect size of the proposed unit concerning the development of the intended cultural awareness skills was large. Added to this, Table (4.3) indicates the effectiveness of the proposed unit based on color idioms in developing positive attitudes among nonspecialist students of English at Port Said Faculty of Education toward translation. Data analysis resulted that mean scores were $(\mathbf{1 0 0 . 5 5})$ for the experimental group. Using the Blake Modified Gain Ratio revealed that gain ratio was $(1.33)$, a value larger than $(0.05)$ implying that the effect size of the proposed unit concerning the development of attitudes toward translation was large. Based upon, the third hypothesis is verified.

The above finding corroborates the findings of other related research studies Alotaibii (2020), Al-Adaileh (2012), Ahmadi, S \& Ketabi, S. (2011). El-Tantawi (2011), Chielens (2007), and Wunderle (2006). A possible interpretation of this finding might be that the included tasks, activities and learning experiences, as opposed to traditional ones, provided multiple opportunities for the participating sample to delve into cultural awareness skills into deeper levels. A second possibility is that the proposed unit based on teaching color idioms in English was engaging, relevant, and giving the trainees good chances to organize their ideas in a logical and coherent manner. A third possible interpretation of this finding might be that the objectives and scope of the proposed unit were clearly defined, and its periodic feedback during training was positive. Seemingly, these aspects 
Effect of a Proposed Unit on Color Idioms on Developing Cultural Awareness and Attitudes toward Translation among Non-specialist Students of English

Dr. Maged Mohammedain

urged the participating sample to be continually interested, focused during practicing the included tasks and activities.

\subsection{Pedagogical Implications}

Several pedagogical implications can be drawn from the present study. For instance, EFL textbooks devoted for non-specialist students should introduce more color idioms in EFL textbooks and provide adequate chances for students to think about color idioms and their meanings. Also, it may be beneficial for EFL teachers to use visuals and conversations to help students understand how the color idioms can be used in real-life situations and everyday communications with other individuals with diverse cultural backgrounds. Added to this, it may be beneficial to compare and contrast color idiomatic expressions prevailed in the English and Arabic cultures to help their students be familiar with the idioms they do not know, and get them comfortable with understanding and using the ones they know. Further, it may be beneficial for EFL students to learn and practice color idiom to make them sound more like native speakers of English. Lastly, EFL researchers should be aware that learning and teaching color idioms can be problematic, particularly when using translation activities as their uses, meanings, and contexts vary widely from one culture to another.

\subsection{Delimitations}

Delimitations are a part of every study. This study, in a certain extent, acknowledges some delimitations that may restrict its conclusions. For instance, it was hard to identify, realize and determine all types of English color idioms suitable and relevant for the non-specialist students of English. Added to this, this study was confined to one group of non-specialist students of English $(\mathrm{N}=22)$ due to the consequences of Covid-19, the researcher's limited time, the researcher's intent to maintain a large focus on the participating sample, and the researcher's intent to ensure that the participating group as a whole was receiving the best possible learning experiences. It would be better to investigate the study variables among a larger sample of non-specialist students of English. Additionally, the dependent variables of this study were confined to cultural awareness skills and attitudes towards translation. It would be better to include other influential variables such as age, scientific specialization or gender of students.

\subsection{Conclusion}

The aim of the study was to analyze the effect of teaching a proposed unit based on translation of color idiomatic expressions in English into Arabic on the development of students' cultural awareness skills and attitudes toward translation. The analysis of the data demonstrates that color idioms are problematic as well as beneficial, as varying widely in their uses and 
Effect of a Proposed Unit on Color Idioms on Developing Cultural Awareness and Attitudes toward Translation among Non-specialist Students of English

Dr. Maged Mohammedain

meaning from one culture to another, providing students more chances to delve deeper into how ideas, values, customs, feelings and arts are structured collectively in a specific culture. In other words, learning color idioms through a well-constructed instructional unit, as the one proposed in this study, can develop students' cultural awareness and attitudes towards translation use because learning color idioms can provide learners more knowledge of social customs, habits, politics, literary, and religious beliefs of people in other cultures. It is worthwhile noting that the proposed unit was presented in this study with suitable teaching materials and considerable tasks of translation to get students engaged in the learning activities that were likely to achieve the intended outcomes of the study. Overall, the four hypotheses put forward in the present study were borne out, revealing a substantial impact of the proposed unit on the development of cultural awareness skills and attitudes toward translation of the participating sample. These findings were supported by a number of prior studies such as those undertaken by Alotaibii (2020), Farooq, et al., (2018), Abdzadeh (2017), Abushihab (2016), Bowman, et al., (2016), Alsamani (2014), Al-Adaileh (2012), El-Tantawi (2011), and Chielens (2007).

\subsection{Recommendations}

Based on the findings of the study, the following are recommended:

- To encourage non-specialist students of English should possess a good vocabulary on both English and Arabic to understand meanings of color idioms.

- To urge EFL teachers to devote more attention to cultural awareness skills, and explore the ways in which color idioms can be more memorable to their students.

- To further research strategies used by language learners to shift from the surface meaning of a given idiom to its deep meaning.

- To expose non-specialist students of English to a lot of idiomatic translation practices to overcome the difficulties they have in dealing with other people belonging to other cultures.

\subsection{Suggestions for Further Research}

Based on the findings of the study, the following studies are suggested:

○ To carry out further research on the strategies EFL students use to better learn and comprehend the meanings of the color idioms.

$\bigcirc$ To investigate effect of the teacher's role as a language facilitator in the development of cultural awareness of students..

- To carry out the same research using a large sample of individuals from different backgrounds and different universities.

$\circ$ To investigate the role of context on interpreting color idioms' meanings. 
Effect of a Proposed Unit on Color Idioms on Developing Cultural Awareness and Attitudes toward Translation among Non-specialist Students of English

Dr. Maged Mohammedain

\section{References}

Abdzadeh, Y. (2017). Raising cultural awareness in Iranian English language classroom: Can a tailored course make a difference? (Doctoral dissertation, University of Southampton, 2017).

Abel, B. (2003). English idioms in the first and second language lexicon: A dual representation approach. Second Language Research, 19, 329358.

Abushihab, I. (2016). The effect of cultural awareness on motivating students to learn English as a foreign language in Jordan. Journal of Foreign Languages, Cultures and Civilizations, 4(1), 51-57.

Ahmadi, S \& Ketabi, S. (2011). Translation Procedures and Problems of Color Idiomatic Expressions in English and Persian: Cultural Comparison in Focus. The Journal of International Social Research. 17/4: 9-39.

Al-Adaileh, A. (2012). The connotations of Arabic color terms. Retrieved from: http://www.phil.muni.cz/linguistica/art/al-adaileh/ada001.pdf. [Accessed on 16.03.2019]

Allan, K. (2009). The connotations of English color terms: Color-based Xphemisms. Journal of Pragmatics, 41, 626-637

Alotaibii, J. W. (2020). Color Idioms in both English and Arabic: Their meanings and Color Associations. European Journal of English Language Teaching, 5, 2: 97-109

Alsamani, A. (2014). Foreign culture awareness needs of Saudi English language majors at Buraydah community college. English Language Teaching, 7(6), 143-153

Al Zahrani, H. (2018). Translation of Idioms on the Cultural Level: Problems and Solutions. Paperback - 28 Mar. 2018

Arabski, J. \& Wojtaszek, A. (2011). Aspects of culture in second language acquisition and foreign language learning. Berlin, Springer.

Atay, D. (2005). Reflections on the cultural dimension of language teaching. Language and Intercultural Communication, $5(3$ \& 4), 222-237.

Atay, D., Kurt, G., Çamlıbel, Z., \& Kaslıoğlu, Ö. (2009). The role of intercultural competence in foreign language teaching. Inonu University Journal of The Faculty of Education, 10(3), 123-135.

Aydemir, E., \& Mede, E. (2014). Integrating target culture in EFL classrooms. Turkish Online Journal of Qualitative Inquiry, 5(1). 1338.

Baker, M. (2011). In Other Words: a Coursebook on Translation. London: Routledge.

Barany, K. L. (2016). Language Awareness, Intercultural Awareness and Communicative Language Teaching: Towards Language 
Effect of a Proposed Unit on Color Idioms on Developing Cultural Awareness and Attitudes toward Translation among Non-specialist Students of English

Dr. Maged Mohammedain

Education. International Journal of Humanities and Cultural Studies I., 2, 4, 257-275.

Belli, S. A. (2018). A study on ELT studentse cultural awareness and attitudes towards incorporation of target culture into language instruction. Journal of Language and Linguistic Studies, 14(1), 102124.

Bowman, N. A., Denson, N., \& Park, J. J. (2016). Racial/Cultural awareness workshops and post-college civic engagement: A propensity score matching approach. American Educational Research Journal, 53(6), 1556-1587.

Byram, M. (2012).Language awareness and (critical) cultural awarenessRelationships, comparisons and contrasts. Language Awareness, 21(1-2), 5-13

Cakir, I. (2006). Developing cultural awareness in foreign language teaching. Turkish Online Journal of Distance Education - TOJDE, 7(3), $154-161$.

Chielens, D., Loes. (2007). Basic color terms in English: An examination of their use and meaning in English expressions. Ph. D. Dissertation, Gent University

Corbett, J. (2003). An intercultural approach to English language teaching. Multilingual Matters Ltd. Great Britain.

Dahroug, H. (2007). The effect of using metacognitive strategies on improving translation skills of prospective teachers of English. Unpublished M.A. Thesis. Faculty of Education, Suez Canal University.

Dordevic, V. L. (2009). On Color Idioms in Economic Discourse. Economski Horizonti. 11/2: 113-121.

Dweik, B. S., \& Al-sayyed, S.W. (2015). Attitudes of Jordanian students, teachers and educationalists towards including culture in EFL classes and textbooks "Action Pack 12". International Journal of Social Sciences, 40(1), 1126-1141.

Dumitrascu, A. M. (2007). Patterns of idiomacity in English, Italian and Romanian. Journal of Language and Linguistic Studies, 3, (1).

El-Tantawi, H. (2011). The Effectiveness of a Remedial program Based on Error Analysis in Developing Secondary School Students' Translation Skills. Unpublished M.A. Thesis. Institute of Arab Research \& Studies: Cairo.

Farooq, M., Soomro, F., Umer, M. (2018). English language teaching and cultural implications in Saudi Arabia. International Journal of English Linguistics, 8(3), 177-185.

Galal, M. M. (2014). Towards raising conceptual awareness: English Arabic idioms of equivalent linguistic form and different 
Effect of a Proposed Unit on Color Idioms on Developing Cultural Awareness and Attitudes toward Translation among Non-specialist Students of English

Dr. Maged Mohammedain

conceptual foundations. International Journal of English Language and Linguistic Research, 2 (3). 29- 55

Grant, L \& Bauer, L. (2004).Criteria for Re-defining Idioms: Are We Barking up the Wrong Tree? Applied Linguistics. Volume 25, Issue 1: 38-61.

Guineg, M. (2012). Exploration of Cultural Similarities and Differences in Custom loaded Idioms between English and Chinese. International Review of Social Sciences and Humanities. 4/1:108-112.

Habeeb, A. and Ahmed, M. \& Abu el-Reesh, M. (2016). The Impact of a Suggested Practical Programme on Improving Arts of English Seniors' Translation Competences at the Islamic University of Gaza and Their Attitudes Towards Translation. Arab World English Journal (AWEJ). (5).

House, J. (2015). Translation quality assessment: past and present. Londres: Routledge.

Hasan, A. A., Al-Sammerai, N. M., \& Bin Abdul Kadir. F. A. (2011). How colours are semantically construed in the Arabic and English culture: A comparative study. English Language Teaching, 4, (3), 206-213.

Hesar, M., P., K., M.Y., \& Zarfsaz, E. (2012). Why and how to apply culture in an EFL classroom? International Conference on Language, Medias and Culture (IPEDR), 33, 68-72.

Ho, S. T. K. (2009). Addressing culture in EFL classrooms: The challenge of shifting from a traditional to an intercultural stance. Electronic Journal of Foreign Language Teaching, 6 (1): 63-76.

Howwar, M. (2013). Seeking the nature of idioms: A socio-cultural study in idiomatic English and Arabic meanings. International Journal of Scientific and Research Publications (3)2, 1-3.

Javdani, F., \& Mahboudi, H.R. (2012). The teaching of English in Iran: The place of culture. Journal of Language and Culture, 3 (5), 87 - 95.

Kahraman, A. (2016). Teachers and learners attitudes towards culture and culture learning in a Turkish context. Journal of Language and Linguistic Studies, 12(2), 01-12.

Karabınar, S., \& Güler, C. Y. (2012). The attitudes of EFL teachers towards teaching culture and their classroom practices. Journal of Educational and Social Research, 2(2), 113-126.

King, T. (2005). Human color perception, cognition, and culture: why "Red" is always red. The Reporter, 20(1), 1-12. https://doi.org/10.1117/12.597146

Kourova, A., \& Modianos, D. (2013). Inter-cultural Awareness and its Role in Enriching Students' Communicative Competence. The International HETL Review. Special Issue 2013 (pp. 60-70 
Effect of a Proposed Unit on Color Idioms on Developing Cultural Awareness and Attitudes toward Translation among Non-specialist Students of English

Dr. Maged Mohammedain

Kovecses, Z. (2010). Metaphor and culture. Acta universitatis Sapientiae, Philogica. 2 (2)197-220.

Lawson-Davenport, M. L. (2014). Examining the relationship between cultural awareness and multicultural self-efficacy in community college instructors. (Doctoral Dissertation). Retrieved from https://search-proquest-com.ezproxy.rowan.edu

Lee, K-Y. (2009). Treating culture: What 11 high school EFL conversation textbooks in South Korea Do. English Teaching: Practice And Critique, 8, 76-96.

Liu, D. 2012. Translation and Culture: Translating Idioms between English and Chinese from Cultural Perspective. Theory and Practice in Language Studies. 11/2: 2357-2362.

Lum, D. (2010). Culturally competent practice $\left(4^{\text {th }}\right.$ ed.), Culturally competent practice.. Belmont, CA: Brooks/Cole, Cengage Learning

Mao, W. (2009). Teaching culture within and beyond language. English Language Teaching, 2(4), 144-148.

Mazurova, V. 2009. "Color Terms in English Idioms". http://cc.joensuu.fi/linguistics/idioms2006/abstracts/mazurova.pdf.

McEachorn, G. (2010). Study of allocated social studies time in elementary classrooms in Virginia: 1987-2009. Journal of Social Studies Research, 34(2), 208-228.

McKay, S. L. (2003). The cultural basis of teaching English as an international language. TESOL Matters, 13(4).

Mekheimer, M. (2012). Assessing Aptitude and Attitude Development in a Translation Skills Course. CALICO Journal, 29(2), p-p 321-340.

Naqeeb, H. (2012). Promoting cultural literacy in the EFL classroom. Global Advanced Research Journal of Educational Research and Reviews, 1(4), 41-46.

Nieto, C., \& Booth, M. Z. (2010). Cultural competence: Its influence on the teaching and learning of International students. Journal of Studies in International Education, 14(4), 406-425.

Nolan, J. (2005). Interpreting: Techniques and Exercises. Professional Interpreting in the Real World. Cromwell Press Ltd.: Great Britain, 2-5.

Önalan, O. (2005). EFL teachers ${ }^{\text {ee }}$ perceptions of the place of culture in ELT: A survey study at four universities in Ankara/Turkey. Journal of Language and Linguistic Studies, 1(2), 215-235.

Ping, Wang (2018), Cutural Characteristics of Idiomatic Expressions and Their Approaches of Translation, Journal of Literature and Art Studies, Vol. 8, No. 2, 295-300 
Dr. Maged Mohammedain

Rahali, S. (2013). The Effect of the Foreign Culture on Learners' Reading Comprehension through the Secondary School Textbook "Getting Through" (Master Thesis). University of Biskra, Algeria.

Rezaeifard, F., \& Chalak, A. (2017). The impact of linguistic and cultural imperialism on Iranian ELT context: attitudes of teachers and students. Journal of Applied Linguistics and Language Research, 4(6), 124-135.

Rodríguez, M. (2017). Culture in the foreign language classroom. $\mathrm{HOW}$ Journal, 10(1), 67-72.

Sarıçoban, A., \& Çalışkan, G. (2011). The influence of target culture on language learners. Journal of Language and Linguistic Studies, 7(1), 7-17.

Rogoff, B. (2003). The cultural nature of human development. Oxford University Press.

Russell, W. B., \& Waters, S. (2010). Instructional methods for teaching social studies: A survey of what middle school students like and dislike about social studies instruction. Journal for the Liberal Arts and Sciences, 14(2), 7-14.

Salamah, D. A. (2015). An investigation of idiom comprehension and translation by translation students at KSU. Arab World English Journal (AWEJ), 6(3), 293-308.

Salim, J.A. \& Mehavesh, M. (2013). Color Idiomatic Expressions in the Translation of Naguib Mahfouz's Novel "The Thief and the Dogs": A Case Study. International Journal of English Linguistics. 4/3:107116.

Shemshadsara, Z. (2012). Developing cultural awareness in foreign language teaching. English Language Teaching, 5(3), 95- 99.

Shojaei, A. (2012). Translation of idioms and fixed expressions: strategies and difficulties. Theory and Practice in Language in Language Studies, 2(6), 1120-1229.

Sewell WH, Jr (2005) Logics of History: Social theory and social transformation. Chicago, IL: University of Chicago Press.

Teleiba, A. (2004). A Suggested Programme for Developing Some Basic Translation Skills of English Majors and Its Effect on Their Attitudes towards Translation. Unpublished Dissertation: South Valley University Qena.

Tomalin, B. \& Stempleski, S. (2013). Cultural Awareness. Oxford University Press, Oxford

Tomlinson, B., \& Musuhara, H. (2004).Developing cultural awareness. MET, 13(1), 1-7. 
Effect of a Proposed Unit on Color Idioms on Developing Cultural Awareness and Attitudes toward Translation among Non-specialist Students of English

Dr. Maged Mohammedain

Turner, D. (2009). Cross-culture color: deep-rooted associations shape reaction to color. Retrieved from http://www.colorturners.com/pdf/Vision_CulturalColor.pdf

Violetta b. (2015). Idiom learning materials for Estonian Secondary School students. Unpublished MA thesis. Estonia. University of Tartu

Wunderle, W. D. (2006). Through the lens of cultural awareness: a primer for US Armed Forces deploying to Arab and Middle Eastern countries. Fort Leavenworth, KS : Washington, DC: Combat Studies Institute Press.

Xin, W. (2012). Semantic Comparison between Chinese and English Idioms Containing Color Words. Canadian Social Science. 8/5:174-177.

Yagiz, O. \& Izadpanah, S. (2013). Language, culture, idioms, and their relationship with the foreign language. Journal of Language Teaching and Research, 4 (5). 953-957.

Yang, C. (2010). Cultural Differences on Chinese and English Idioms of Diet and Translation. English Language Teaching. 3/1:148-154.

Zarei, A. and Pour, V. (2013). Language learning strategies as predictors of L2 idioms comprehension. International Journal of Language Learning and Applied Linguistics World, 4(2), 330-313.

Zhao, Y. (2009). An empirical study of L2 learners' use of lexical chunks and language production (Master's thesis, Kristianstad University College, Kristianstad, Sweden). Retrieved December 15, 2019 from http://www.diva-portal.org/smash /get/diva2:229050/FULLTEXT01.pdf

Zhao, B. (2010). How to enhance cross-cultural awareness in TEFL. CrossCultural Communication, 6 (2), 100-104 